\title{
6o- Battle for truth: A COVID-19 patient's monologue ${ }^{1}$
}

\section{Esma Nur ÇETINNAYA KARADAĞ ${ }^{2}$ \\ Zeliha KURUDUCU3}

APA: Çetinkaya Karadă̆, E. N.; Kuruducu, Z. (2021). Battle for truth: A COVID-19 patient's monologue. RumeliDE Dil ve Edebiyat Araştırmalar Dergisi, (25), 1009-1019. DOI: $10.29000 /$ rumelide.1032564.

\begin{abstract}
David Hare tells a Covid-19 patient's experience in his play Beat the Devil: A Covid Monologue staged in 2020. Starting from his own Covid-19 experience, Hare sheds light on an old individual's Covid-19 process. Since he does not know how the virus influences him, he loses confidence in the health sector and the government's Covid-19 politics. The text shows the older man's lonely struggle for finding the truth in a post-truth era when the truth can be quickly warped through politics and media in an interrelated way. Covid-19 was the last hit of the global problems such as malnutrition, poverty, refugee crisis, AIDS epidemic, access to clean water in a so-called well-developed world in the last century. Despite the scientific advancements, scientists have confronted difficulties understanding the scope of the global problem that humanity faces today. For so long, there have been ongoing discussions on the concept of post-truth and its central role in state politics in terms of economy and policies on the human subject. The critical issue is whether Covid-19 is linked to the politics of 'power' and 'knowledge' on a political level or a health problem on a scientific level. Hare's play portrays the untold misery and suffering of millions of people who had to stay home without knowing the scope of the threat outside. This study aims at interpreting the conditions mentioned above in a theoretical way.
\end{abstract}

Keywords: Biopolitics, Covid-19, David Hare, post-truth, power

\section{Hakikat mücadelesi: Bir Covid-19 hastasının monoloğu}

\section{$\ddot{O} \mathbf{z}$}

David Hare 2020 yllında sahnelenen Beat the Devil: A Covid Monologue oyununda bir Covid-19 hastasının tecrübesini aktarır. Kendi Covid-19 tecrübesinden hareketle, Hare, yaşlı bir bireyin Covid19 sürecine ışık tutar. Virüsün kendini nasıl etkilediğini tam manasıyla bilmediğinden, sağlık sistemine ve hükümetin Covid-19 politikalarına inancını yitirir. Metin, hakikatin politika ve medya aracılığıyla birbiriyle bağlantılı şekilde hızla çarpıtılabileceği hakikat-sonrası bir çağda, insanın hakikate ulaşmak için verdiği yalnız mücadelesini gösterir. Sözde gelişmiş bir dünyada, Covid-19 yetersiz beslenme, yoksulluk, mülteci krizi, AIDS hastalı̆̆ı, temiz suya erişim gibi küresel krizlere son darbesi olmuştur. Bilimsel ilerlemelere rağmen, bilim insanları insanlı̆̆ın bugün karşı karşıya kaldığı küresel krizin boyutunu anlamakta zorlandılar. Hakikat-sonrası kavramı ve bu kavramın ekonomi ve

\footnotetext{
1 Bu makale 7th BAKEA International Western Cultural and Literary Studies Online Symposium'unda (15-16-17 Eylül 2021 tarihinde) bildiri olarak sunulmuştur.

Öğr. Gör., Recep Tayyip Erdoğan Üniversitesi, Rektörlük (Rize, Türkiye), esmanur.cetinkayakaradag@erdogan.edu.tr, ORCID ID: oooo-0003-1940-7364 [Araştırma makalesi, Makale kayıt tarihi: 19.10.2021-kabul tarihi: 20.11.2021; DOI: 10.29000/rumelide.1032564]

3 Öğr. Gör., Karabük Üniversitesi, Yabancı Diller Yüksekokulu (Karabük, Türkiye), zelihakuruducu@karabuk.edu.tr, ORCID ID: 0000-0002-4337-5983
} 
insan konusundaki politikalar açısından devlet siyasetindeki merkezi rolü üzerine uzun süredir devam eden tartışmalar mevcuttur. Kritik konu, Covid-19'un siyasi düzeyde 'iktidar' ve 'bilgi' siyasetiyle mi yoksa bilimsel düzeyde bir sağlık sorunuyla mı bağlantılı olduğudur. Hare'in metni, aslında dışarıdaki tehdidin boyutunu bilmeden evde kalmak zorunda kalan milyonlarca insanın anlatılmamış sefaletini ve ıstırabını anlatıyor. Bu çalışma, yukarıda bahsedilen koşulları teorik olarak yorumlamayı amaçlamaktadır.

Anahtar kelimeler: Biyopolitika, Covid-19, David Hare, hakikat-sonrası, iktidar

\section{Introduction}

David Hare's latest play, Beat the Devil: A Covid Monologue, is based on his Covid-19 experience. Based on the idea that the personal is political, Hare narrates his personal story; how he got sick and got better over time. Even though he is accompanied by his wife Nicole at home, Hare sees that he is desperate about his health and feels insecure about the deficiency of governmental tools. The plot revolves around the anxiety and the rage of an individual who feels stuck between a novel disease and the conservative British government's health policies. He tells the shortcomings of those policies when the virus spreads to both his body and the whole country. Hare employs a sarcastic tone to present the weakness of the health policies. The use of sarcasm and representation of politics are familiar elements of Hare's political theatre. His famous works such as Pravda (1985), Murmuring Judges (1991), The Absence of War (1993), Via Dolorosa (1999), The Power of Yes (2009), and I'm Not Running (2018) also have the characteristics of political theatre.

First, the text Beat the Devil: A Covid Monologue was successfully adapted for stage performance in the form of soliloquy in August 2020, soon after the early months of the global health crisis. After the first lockdown in the UK, the play was staged at Bridge Theatre in London (Hare, 2021, p.6). The text focuses on Hare's hazy mind, which is full of unanswered questions about the unstoppable spread of the virus, health policies, increasing social inequalities, and the shortcomings of the prime minister in the UK. He stresses that Germany and New Zealand are the role-model countries that work hard to beat the virus, referred as the devil in the text. The text allows the reader to evaluate what goes on around people politically. Thus, it is reasonable to claim that Hare's text is an essential historical document that portrays a person's social and personal story under the Covid-19 crisis.

Second, Hare puts the theme, an individual search for truth in a tough time of humanity at the centre of the text. The emergence of Covid-19 once more proved that there are inevitable discussions on the word 'truth' and 'power' on a political and scientific basis. This study will present an insight into the global Covid-19 crisis by highlighting Hare's mind, struggling to attain the truth about his health and the government's health policies. To that end, we use the concept of post-truth and its central role in politics to elaborate the text. In the first half of the study, we aim at giving general information about the word 'post-truth' under the title of 'post-truth predicament.' In the second half, Hare's autobiographical text is deconstructed accordingly. The concepts that foreground the discussions here are primarily biopolitics, post-truth, and power.

\section{From Truth to Post-truth Predicament}

It will be impossible to give a precise definition of the word 'truth' and the 'post truth' literally because it is not easy to capture the new dimensions that require a necessity to review the additional meanings 
of each word. Moreover, within time ongoing changes and inevitable conversions also cause new spectrums that blur the definitions of each concept accordingly. It is essential to go back in time and review the old explanations first and check what has been said about the word 'truth' that haunts the academy and philosophy. However, the objective here is only focusing on a socio-political and scientific level of it.

For anyone who has followed the works in academy especially, after the late capital period, the most potent and impressive studies on the concept 'truth' with its new interpretations are Michel Foucault's -from Lectures on The Will To Know (1970-1971), the History of Sexuality Vol I: The Will to Knowledge (1976), The Birth of Biopolitics (1978), The Courage of Truth (1983-1984), and Fearless Speech (1983; 1st ed. 2001). In these studies, Foucault's analysis of the 'truth' concept is reinterpreted with the concept of the 'power.' Theoretically, Foucault asserts that "truth isn't outside power" or "lacking in power" (Foucault, 2010, p.1668). The fact is that truth, not something that is reached after lots of struggles or any privilege for some, whereas "truth is a thing of this world: it is produced only under multiple forms of constraint," and he adds that truth is "induces regular effects of power" (Foucault, 2010, p.1668). Foucault points out the bounded relation between each concept: truth and power. Furthermore, truth says Foucault has turned out various forms regarding each society and its dimensions in time. He talks about the point as such:

each society's general politics of truth: that is the types of discourse which it accepts and makes function as true and false statements, the value in the acquisition of truth: the status of those who are charged with saying what accounts as true (Foucault, 2010, p.1668).

His analysis points to the fact that modern societies, especially the developed ones, cannot separate themselves from the political economy, characterized by power and knowledge dynamics. For Foucault, as a "political power," the demand for truth is in the form of scientific discourse, and the institutions produce it in the form of political and economic apparatus' such as university, army, media, academy. (Foucault, 2010, pp.1668-1669). Foucault states, "there is a battle 'for truth,' or at least 'around truth" (Foucault, 2010, p.1669). According to Foucault, the necessary point is to think about political problems with the terms 'truth' and 'power' rather than 'science' and 'ideology' (Foucault, 2010, p.1669).

What is crucial and catching in Foucault's theoretical affirmations highlighted here is that they provide an appropriate framework for analyzing the concept: truth. It also opens a door for the intellectuals who must recapture the meanings of truth and post-truth in turn accordingly. As he offers, each concept cannot be separated from political arenas' power relations and policies.

Having given an account of Foucault's main ideas, at this point, Baudrillard tells us something more on the subject matter highlighted here. Baudrillard, who has been deeply influenced by contemporary French thought, including Foucault himself, makes his framework using significant concepts such as implosion, semiurgy, simulation, and hyper-reality. Like Foucault, his works are valuable and controversial, containing many new and breath-taking views in social studies. One of his main interests, likewise Foucault, is the dimensions of truth and reality that show themselves in (re)new forms. In Baudrillard's writings, the era in which at the same time he lives is described as much more different from the old modern order. With the new developments and experiences by a capitalist culture industry, the society moves from industrial to postmodern order, shaped by mass media, information, communication, and signs. According to Baudrillard, these are the primary thresholds that he considers when formulating his theory of 'mass society' (Sarup,1993, p.168). He asserts that the concepts such as truth, reality, society, power, meaning have been erected from industrial to post-industrial society 
(Sarup, 1993, p.168). Moreover, he comes to the point that "there is ultimately no difference between fictive and other, truth-telling forms of discourse; truth and falsity are wholly undisguisable" (Sarup, 1993, p.168). Baudrillard's position on the critique of truth and the stable referents of the Enlightenment project is the out fashioned, hopeless concepts. As Sarup states: 'There is simply no appeal beyond the structures of representation, the discourses, that determine what shall count as knowledge or truth within a given interpretive concept' (Sarup, 1993, p.168).

Both critics' approaches to truth and its present condition are different but not contradictory. Here, Baudrillard reads that the truth no longer existed. The clear distinction between the real and the image has no longer occurred. There has been erosion between the old oppositions in time. According to Baudrillard, with the new condition of the post-industrial world, everything is 'hyper-real' -in excess of itself (Sarup, 1993, p.165). Foucault promoted the idea that 'power produces reality; it produces domains of objects and rituals of truth [...] The exercise of power creates and causes new objects of knowledge (Sarup, 1993, p.74). The formulation suggested by Foucault presents that "truth is a thing of this world, and it is produced" (Foucault, 2010, p.1668). In contrast, according to Baudrillard, truth is regarded as nothing more than a 'representation.' Furthermore, Foucault's approach to truth leads him to consider the concept a kind of political practice. However, Baudrillard's position leads him to (re)capture it as a cultural practice.

The inevitable fact is that truth constantly changes its direction within time and circumstances. At present, the truth is much stranger than it used to be. Considering the events of Hannah Arendt's 1963 report from the trial of Adolf Eichmann, the Brexit Referendum in England in 2016, Donald Trump's 2016 Presidential Campaign, it is argued that reality has started to make its presence in a different form within a different route. Thus, a new term emerged aiming for defining the recent phenomenon circling the world. That is post-truth. According to the Oxford Dictionary, post-truth is defined as "relating to or denoting circumstances in which objective facts are less influential in shaping public opinion than appeals to emotion and personal belief" (Oxford Dictionaries, 2021). Each event highlighted above is the referents and best examples that project the meaning of the term post-truth.

Like Baudrillard, by being worthy of Foucault's works and influenced mainly by him, a living critic Byung-Chul Han provides many impressive studies on this subject matter. Han's primary interest is 'the condition of posthuman' and its relation to 'post-truth' by (re)interpreting the new situations at the centre of the present era. Having given an account of Foucault's and Baudrillard's main ideas, Han makes the following criticisms of his time in his works. He goes further in his discussions by considering the new post-industrial, digital, and finally virus era.

As the line between truth and lies becomes uncertain and murky at present, it is regarded that the truth is not much more than a dangerous 'propaganda tool.' Han best connects each term and its new form with the ongoing condition of the modern world. He one more time underlines the relationship between truth and politics by referring to their bounded relation with a new phenomenon, digitalism. According to Han, today is a part of a long historical drift of capitalist thinking that determines historical, political, social, and philosophical matters. Furthermore, he continues his assertions as such: many years after the Cold War, now it seems that "globalization eliminates everything" -societies with borders, fences, etc. "to give free rein to capital". For the sake of "accelerated circulation of goods and capital," the system has to dispose of the "immune thresholds" in its body. Then, digitalism becomes its place, serving as "eradicating the reality" (Han, 2020). On the one hand, the "reality is eradicating"; on the other hand, post-truth eliminates the truth and lies by circling the system (Han, 2020). In return, the 
governments quickly assert their new political tactics without considering the facts or any reasonable guideline behind them.

At present, the modern man finds himself in such a tragic situation. Finally, Hare's experiences on a political and personal level become blurred, unstable, and much more challenging to make sense of them. Therefore, Hare stands up for the facts and hopelessly questions every piece of information and news in his personal and artistic life. Indeed, not only for Hare but also for all of us truth has never been much more crucial than before.

\section{Battle for Truth}

At the beginning of the text, we learn that David Hare caught the Covid-19 and is in total obscurity about his health situation. The only thing he feels is the taste of sewage in his mouth, yearning for freshwater. Although he learns about the common symptoms, his symptom is not listed as expected, making him anxious. Even the medical professionals cannot give him a clear answer. Because the risky atmosphere of modernity is threatening everyone, even the experts of a scientific field can be inadequate in new situations (Giddens, 2019, p.168).

Hare refers to the famous description of the virus: "No virus is known to do good: it has been well said that a virus is "a piece of bad news wrapped up in protein" (Medawar and Medawar, 1983, p.275). Hare chronologically explains how the bad news affects him and other people in the UK throughout the text. First, he gives a background explanation of how he got the virus at Oxford Circus, where he had worked on a new TV series with two of his friends, the editor, and the director. We learn that Hare's new project is about "a Conservative politician who is forward-looking, intelligent, charismatic and popular. It's not based on anyone in real life." (Hare, 2020, p.7). His sarcasm is evident in his words because Hare himself, as a political playwright, never avoids writing on the weaknesses of the conservative politics in the UK government. He frankly states that he cannot trust prime minister Boris Johnson's performance to deal with the Covid-19 issue. Johnson has already skipped some other governmental responsibilities, such as the COBRA meetings (Walker, 2020). Johnson's calm attitude to announce total measures because of his focus on his private life shows his weakness in the contagion process. Johnson's divorce and his girlfriend's pregnancy seem to occupy him more than the newly introduced crisis. Furthermore, the pretension of Johnson as if he is endowing freedom to the British people by not restricting, they are going to inns and public houses makes Hare angry. Because he knows that those spaces since their birth have often been regulated in the UK either secretly or frankly. Therefore, Johnson attempted to disguise his inadequacy in processing the spread of the virus.

When Hare cannot breathe properly, he understands that his lungs are under threat. He infers that "temperature, heart rate, blood pressure, respiratory rate, and oxygen saturation" (Hare, 2020, p.8) are the vital cinque in this disease. However, he soon understands that "There's no correlation between oxygen saturation and how much oxygen is reaching the vital organs." (Hare, 2020, p.8). At this point, doctors' inefficacy to explain this disease exactly tears down the signifiers of the twenty-first-century scientific advances. So, he thinks, "Ok, so it may be humbling for the medics, but for me and people like me, a better word is 'alarming' (Hare, 2020, p.9)”.

Hare also observes his wife's approach to the Covid-19 and states that; 'Nicole's convinced that she'll never get ill. Her mother lived to a hundred and two' (Hare, 2020, p.11). Nicole here represents a mediocre person who is not fully aware of the risks of this virus, and she believes that nothing will 
happen to her because her genes are stable. However, her unconscious attitude stems from the lack of proper guidance by the government. Since the government has failed to declare a state of emergency related to the newly spreading virus, people ignore it.

Even though Hare initially stated that his new project is not based on a real-life, conservative character, the monologue continues attacking the Conservative government. Because the country has been open to visitors from viral centers and the herd immunity policy has been proposed to overcome the virus. Hare, as an individual, wonders why the government did not follow WHO's advice beforehand. He does not indicate a name, but we understand that the unmentioned name is the PM as readers. The debate whether the lockdown or spread testing will help the country overcome the disease costs a lot. The necessary precautions that were not taken in time do not make sense because he already started to feel dismantled.

Hare reveals his ideas about the increasing social inequalities with the spread of the virus. He sees that the medics are not equipped with protective clothes before encountering the Covid infected patients. In a sense, they are 'naked' bodies who had to fight in the front line of this war (Hare, 2020, p.14). Care homes where the most vulnerable people stay are neglected during the pandemic, and the death rates are alarming in those places. As an individual, he cannot understand this ignorance.

In the ninth part of the monologue, Hare criticizes Donald Trump's way of despising the virus. Trump believes that if you denigrate your opponent without hesitating to be true or untrue, you can win. This has always been his strategy not only in his electoral campaigns but also in his life. It seems that Trump is applying the same tactic to the virus. To Trump, 'Sick people are losers' (Hare, 2020, p.14) and those Unwertes Leben (Life unworthy of life) are the obstacles in a rational order. They need to be eliminated to brighten the perfect harmony on Earth (Bauman, 2018, p.235). However, this time the virus is more potent than his slogans or humiliation of the virus.

Hare surprisingly notices that Trump's view about the sick people is adopted even by his friends: 'A famous film director remarks to me that I'm the only person he knows who's got it. Do I detect an undercurrent of rebuke, as though it's not the sort of thing the middle classes aren't meant to get?' (Hare, 2020, p.15). It is not novel that politicians reflect the truth differently, but now the internet offers them a novel platform to spread those distorted ideas quickly (Kakutani, 2019, p.62). As a very active user of social media, particularly Twitter, Trump abused the public's fear and created 'alternative truths' and public enemies to manage his electorates well during his campaigns (Kakutani, 2019, p.63). Hare, because of this reason, is angry with the politics of the UK government. Instead of creating a helpful way to deal with the crisis, they imitate the US government, disappointing the people.

Hare, declaring his 'interest in the relationship between public life and untruth' (Hare, 2020, p.19) criticizes Trump as a liar. In the text, he states that 4 percent of claims made by Trump were true based on research conducted by PolitiFact (Hare, 2020, p.19). PolitiFact was established in 2007 to 'look at specific statements made by politicians and rate them for accuracy' (Holan, 2018).

Trump, the most eminent figure of the post-truth era, is blistered in the text several times. Kakutani states that Trump's untruthfulness is so serious that finally, newsagents started to list his lies, his derelictions of duty, and his insults over time. Because Trump's courage to lie easily also encouraged other politicians around him (Kakutani, 2019, p.72). Although Trump is the most significant political figure in terms of lying and distorting the truth, his ideology has naturally surpassed the US borders and 
paved the way for other countries run by democracy on the surface. In Lee Mcintyre's book, Post-Truth, whose Turkish translation's preface is written by Mirgün Cabas, we are warned that today we need to be more intelligent and well-equipped to prize the truths above lies. Because the asymmetrical superiority of lies over truths can only be corrected by serious newspapers, TV channels, or digital platforms such as PolitiFact or teyit.org in Turkey. These platforms help us eliminate the false news which spread fast, especially on social media. People's tendency to support leaders who are lying or despising the truth may be explained by their influence and prestige in society. Personal influence can be provided with wealth, not intelligence or genius (Le Bon, 2020, p.179). This view may help us understand the rise of Trump and conservative politics in the USA.

Hare continues depicting the increasing social inequalities which he observes since the outbreak of the pandemic:

\begin{abstract}
Apparently, I've crossed class lines by carelessly catching a disease which generally attacks manual workers and ethnic minorities. After all, it's already becoming clear that you're twice as likely to die if you're poor. Diseases follow the social gradient.
\end{abstract}

And skin colour. In England and Wales, you're four times as likely to die ifyou're black(Hare, 2O2O, p.15).

The subject, adopting middle-class values, always tries to get the best for himself. The offerings of the system surround him, and if he is unsuccessful despite those offerings, he is the one to be blamed for. Because his successful performance is expected in all areas of life. In line with Trump's ideology, the neoliberal subject is doomed to survive and succeed (Han, 2019, p.39). The UN also announces the most vulnerable segments of society like Hare's observation. In the medium and long term, it is expected to increase the social inequalities, exclusion, and discrimination if the pandemic is not managed correctly (UN, 2020). Because racial and ethnic minority groups generate the working class of society, their exposure to Covid-19 is naturally earlier and faster than other groups in society (CDC, 2020). In a similar vein with Hare, Slavoj Zizek states that class divisions that we are used to observing in our daily lives now have a new dimension in the pandemic. Because the safe isolation by working from home can only be attainable by some intellectual groups (Zizek, 2020, p.14-15).

However, when the government ministers realize that things are getting worse day by day, they employ another discourse: 'Words like 'failure' or 'mistake' are forbidden and replaced with the anodyne 'challenge' (Hare, 2020, p.16). The ideology of affirmation and optimization of everything is a kind of violence that may help us understand the change of words over time (Han, 2020, pp.38-39) because the harsh truth of the Covid -19 process is distorted differently by changing the words from failure or mistake to challenge. Baudrillard once explained the whole system as 'globally terroristic' because the terror of uncertainty and dissuasion is far stronger than the terror of violence and accidents (Baudrillard, 1993, p.42). In this respect, the biggest fear of Hare throughout the text is his inability to learn what is going on in his body or 'bodies'. With reference to him, the vulnerability of human subjects in such a globally terroristic system has increased. Even though the treatment of AIDS and cancer that Baudrillard sees as modern pathologies is impossible, now the Covid-19 can also be listed as a modern pathology. However, the unexpected outbreak of a modern pathology does not force the government to take immediate precautions. Instead, Hare says that:

Surely, looking abroad to the examples of Angela Merkel in Germany and Jacinda Ardern in New Zealand, something must have stirred inside the head of at least one thinker in Downing Street. Given how well those two leaders were doing, and how badly we were doing, did it really occur to 
anyone in power that possibly following their example and levelling with the public might be a more fruitful political tactic? (Hare, 2020, pp.20-21).

While Hare locates Donald Trump into the hemisphere of corrupt political order, he frankly states that Jacinda Ardern and Angela Merkel have been the two great examples of the Covid-19 process in their countries. Indeed, Hare indicates that Conservative politics in the USA and UK are insufficient, and the left and the Labour party politics are successful. Hare is quite right in his observations because New Zealand's battle with the pandemic is based on 'rapid, science-based risk assessment linked to early, decisive government action,' which are crucial elements in the life-threatening issue (Baker et al., 2020).

Germany was also regarded as a 'German exception' when the fatality rates of Covid-19 are compared with those of EU countries and the UK. Those rates stemmed from the 'early and widespread treatment and testing, plenty of intensive care beds, coupled with decisive government action whose social distancing guidelines are widely observed' (Chalk, 2021, pp.94-95). That is, Hare appreciates the socialist approach of New Zealand and Germany to the Covid-19 process but also their female political leaders in a neoliberal world.

Besides Boris Johnson, Hare also criticizes other ministers, especially the home secretary Priti Patel's saying that she was sorry because people felt there had been failings so far (Hare, 2020, p.17). Hare sees Patel as one of the liars of the Johnson government, and he also attacks her previous secret meetings in Israel even with the Israeli PM Benjamin Netanyahu without informing the Cabinet in 2017. Initially, she claimed to attend only two meetings, but later, it was revealed that she had twelve meetings (Harpin, 2017). In the text, Hare reveals his untrust in Patel because her untruthfulness has already been proved in the country.

Hare refers to three tragic historical events; Hillsborough (1989), Bloody Sunday (1972), and Grenfell Tower (2017), and desperately reminds of the tragic deaths of hundreds:

Has no one in the current government ever met the bereaved? Do they not remember Hillsborough? Or Bloody Sunday? Or the residents of Grenfell Tower?

Have they really not yet learned that the most soothing possible bandage for the wounds inflicted by grief is the truth?

Do the families and friends of the dead not deserve it (Hare, 2020, p.21)?

It is of primary importance that Hare commemorates these three tragic events associating them with the Covid-19 process. Considering right after these events happened, the UK government first blamed the victims and led the advocacy journals to inform the public that the victims caused these tragedies. However, apologies and changing news headlines over time signify that people are vulnerable to the truths presented to themselves during a real crisis. The basic concern of Hare, in this text, is the probability of distorting the Covid-19 truth today.

He intrinsically believes that grief can only be relieved with truth, but the government again prefers to escape from the truth in many ways. He cries that he wishes to be a child to whom the truth is revealed. It seems that uniting in common grief can be a remedy for people to create a bright future because we tend to forget the previous tragedies as humans. Within a Baudrillardian frame of thinking, 'We are doomed in consequence to a whitewashing of all activity - whitewashed social relations, whitewashed bodies, whitewashed memory- in short, to a complete aseptic whiteness (Baudrillard, 1993, p.44). 
Hare's fear that 'Covid-19 will be forgotten just as Spanish flu is forgotten' (Hare, 2020, p.21) stems from his untrust in the social memory weakened by politics.

As the text progresses, we learn that Hare refers to an important date for himself, $6^{\text {th }}$ April 1980, when his first full-length play premiered at Hampstead Theatre. He exuberantly realizes that $6^{\text {th }}$ April is also the day he wins his victory over Covid. Although he has been home for days without wishing to eat or drink anything, that day, he yearns for a croissant which surprises his wife. He feels that a demon is leaving his body like an exorcising session of medieval times. His reference to the word medieval is the second in the text. He quoted the first medieval word from Beverley Hunt, who used it at the beginning of Covid-19 to express how perplexed they were (BBC, 2020). The stress on the word medieval by both the professor and Hare indicates the anomalous situation of the $21^{\text {st }}$ century when the scientific progress of humanity is insufficient to uncover the mystery of this disease. Hare's recuperation from Covid-19 makes him be grateful for simple things in life such as fresh water, tea, or watching a film, but he also sees the unfairness of the illness.

\section{Conclusion}

This study has illustrated the representation of the Covid-19 crisis, which the conservative governments of the UK and the USA poorly handled. The people who want to learn how the virus influences them are left unheard. Boris Johnson's agenda outweighs the health crisis in the country, which leaves millions alone with economic and social troubles. Hare compares the government's attitude to the crisis with Germany and New Zealand and criticizes that conservative politics make things worse for people. He is particularly angry with Donald Trump, who misleads people about the true effects of the Covid-19 using social media. On the one hand, Trump is the representative of corruption in a post-truth era; on the other hand, Jacinda Ardern and Angela Merkel stand for the representative of the Labour Party and the Left, which introduced strategic health precautions without excluding anyone from the system. However, in England, coping with Covid-19 looks like a puzzle which everyone has to solve. Let alone taking lessons from tragedies in the past, Johnson imitates Trump, and as a result, the so-called modern individual is in a crisis with a corrupt mind and body and gets stuck in homes. For everyone in the UK, now the truth is 'a supernatural effort, an elevation to the near-divine' during the pandemic (Beck, 1992, pp.166-167). In a political atmosphere in which politics twist or break the truth, perhaps this has a price: the individuals recline upon sources that have been eroded insidiously. In apocalyptic scenarios, it is generally assumed that end-of-world would stem from nuclear disasters or wars. However, the Covid19 health crisis burst out in the middle of all troubles like a biological bomb. This made people all around the world find themselves in a common ground together in a post-truth era. As Ariboğan notes, the global world finds itself in an existential crisis suddenly that puts the post-industrial society in a much more difficult situation than before (Arıboğan, 2020, p.360). From the perspective of both a dramatist and an individual, David Hare sees that coping with the Covid-19 at home is much more difficult with poor policies and health politics which led to social segregation in terms of the economic capabilities of individuals. Corrupt politicians made the process much more complicated since they could not build mutual trust between them and the citizens. The novel virus has become a devil which left people alone and desperate in their homes. The isolated individuals' struggle to find out the truth about their health and their need for the appropriate guidance of the politicians have turned into an endless battle in the political turmoil system. 


\section{References}

Arıboğan, D. Ü. (2020). Pandemi sonrası dönemde küresel güvenlik ve iş birliği: 19. yüzyıl Avrupa ahenginden 21. yüzyılın küresel ahengine. In, M. Şeker, A. Özer, C. Korkut (Eds.), Küresel Salgının Anatomisi: İnsan ve Toplumun Geleceği (pp. 348-368). Ankara: Türkiye Bilimler Akademisi.

Baker, M. G., Wilson, N., \& Anglemyer, A. (2020). Successful elimination of Covid-19 Transmission in New Zealand. The New England Journal of Medicine, 383(8): e56.

Baudrillard, J. (1993). The transparency of evil: Essays in extreme phenomena (Trans. B. J. St. John). USA: Verso.

Bauman, Z. (2018). Parçalanmış hayat: Postmodern ahlak denemeleri. (Trans. İ. Türkmen). 3rd ed. İstanbul: Ayrıntı.

Beck, U. (1992). Risk society: Towards a new modernity. (Trans. M. Ritter). London: Sage Publications.

CDC (2020, December 10). Risk of Exposure to COVID-19. CDC. Retrieved August 20, 2021, from https://www.cdc.gov/coronavirus/2019-ncov/community/health-equity/racial-ethnicdisparities/increased-risk-exposure.html

Chalk, J. (2021). Neoliberalism and personal freedoms during COVID-19. Pluto Journals, Journal of Global Faultlines, 8(1), 91-99.

Foucault, M. (2010). Power/knowledge: Selected interviews and other writings, 1972-1977. In C. Gordon (Ed.) The Norton anthology of theory and criticism ( ${ }^{\text {nd }}$ ed.) (pp.1668-1669). New York, USA: W.W. Norton Company. (Original work published 1980).

Giddens, A. (2019), Modernite ve bireysel kimlik. (Trans. Ü. Tatlıcan). 3rd ed.İstanbul: Say.

Han, B.C (2019), Psikopolitika: Neoliberalizm ve yeni iktidar teknikleri (Trans. H. Barışcan). $2^{\text {nd }}$ ed. İstanbul: Metis.

Han, B.C. (2020, May 31). The Virus Era: Disease, Solidarity, and Capitalism. Arquitectura Viva. Retrieved Sep 07, 2021, from https://arquitecturaviva.com/articles/la-era-del-virus-3

Hare, D. (2020), Beat the Devil: A covid monologue. London: Faber and Faber.

Hare, D. (2021), We travelled: Essays and poems. London: Faber and Faber.

Harpin, L. (2017, November 17). Priti Patel forced to apologise after meeting Netanyahu in Israel. The JC. Retrieved August 22, 2021, from https://www.thejc.com/news/uk/breaking-priti-patel-didnot-tell-boris-johnson-about-secret-israel-meetings-1.447445

Holan, A.D. (2018, February 12). The Principles of the Truth-O-Meter: PolitiFact's methodology for independent fact-checking. PolitiFact. Retrieved August 22, 2021, from https://www.politifact.com/article/2018/feb/12/principles-truth-o-meter-politifactsmethodology-i/

Kakutani, M. (2019), Hakikatin ölümü: Trump çağında yalancllk sanatı. (Trans. C. Mizrahi). $2^{\text {nd }}$ ed. İstanbul: Doğan Kitap.

Le Bon, G. (2020). Kitleler psikolojisi (Trans. F.Z. Bayra). $1^{\text {st }}$ ed. İstanbul: Hayat Yayın Grubu.

Mcintyre, L. (2019) Hakikat-sonrasi (Trans. M.F. Biçici). $1^{\text {st }}$ ed. İstanbul: Tellekt.

Medawar, P.B., Medawar, J.S. (1983). Aristotle to Zeus: A philosophical dictionary of biology. Cambridge, Mass: Harvard University Press.

Morris, C. (2020, May 23). Coronavirus: 'Baffling' Observations from the front line. BBC. Retrieved August 22, 2021, from https://www.bbc.com/news/52760992

Oxford Online Dictionary (2021). https://www.oxfordlearnersdictionaries.com/definition/english/post-truth?q=post+truth

Sarup, M. (1993). Introductory guide to post-structuralism and postmodernism. Georgia: The University of Georgia Press (Original work published 1988). 
UN (2020). Everyone Included: Social Impact of COVID-19. United Nations. Retrieved August 20, 2021, from https://www.un.org/development/desa/dspd/everyone-included-covid-19.html

Walker, P. (2020, April 19). Boris Johnson missed five coronavirus Cobra meetings, Michael Gove says. The Guardian. Retrieved August 20, 2021, from https://www.theguardian.com/world/2020/apr/19/michael-gove-fails-to-deny-pm-missedfive-coronavirus-cobra-meetings.

Zizek, S. (2020). Pan(dem)ic! Covid-19 Shakes the World. New York \& London: OR Books. 